\title{
A STUDENT FOCUSED EVALUATION OF INTERIOR DESIGN EDUCATION: A DESIGN STUDIO EXPERIENCE
}

\author{
Res. Assist. Dr. Özlem KURT ÇAVUȘ* \\ Res. Assist. Dr. Mustafa ÇAVUȘ** \\ Prof. B.Burak KAPTAN***
}

\begin{abstract}
This article includes a comparison of two student groups which differ according to their previous learning within a design studio course in the department of interior design. The first group is the students who have enrolled in the department through a transition exam applied after the graduation of vocational schools, and the other group consists of standard students who enrolled according to the score of a central exam. The distinguishing feature of the first group is that they have passed to the faculty after two years of vocational education. The transition students have different backgrounds for their previous learning. As it is known, the design studio is an opportune environment to observe the design process and students' performances. Also student factor in design studios is currently being discussed intensively to improve the content of design education. From this perspective, it is aimed to evaluate success circumstances of these two groups scientifically through the design studio environment. The success levels of standard and transition students were compared based on performances of the design studios. Consequently, no statistically significant difference was found depends on the backgrounds of students, however some qualitative inferences were made through interpretation in the scope of the study.
\end{abstract}

Keywords: Design education, Interior design education, Design studio, Studio pedagogy, Student profiles

Received Date: 15.06.2020 Accepted Date: 07.09.2020 Arcticle Types: Research Article

*Eskisehir Technical University, Faculty of Architecture and Design, Department of Interior Design, ozlemkurt@eskisehir.edu.tr ORC ID 0000-0002-9992-2472

**Eskisehir Technical University, Faculty of Science, Department of Statistics, ORC ID 0000-0002-6172-5449

***Eskisehir Technical University, Faculty of Architecture and Design, Department of Interior Design, ORC ID 0000-0002- 4815-8179 


\title{
IÇMIMARLIK EĞiTiMINDE ÖĞRENCI PROFiLi ÓDAKLI BIR DEĞERLENDIRME: BIR TASARIM STÜDYOSU DENEYIMI
}

\author{
Arș. Grv. Dr. Özlem KURT ÇAVUȘ* \\ Arș. Grv. Dr. Mustafa ÇAVUȘ * * \\ Prof. B.Burak KAPTAN***
}

Özet: Bu makale, içmimarlık bölümünde bir tasarım stüdyosu dersinde önceki öğrenimlerine göre farklılık gösteren iki öğrenci grubunun bir karşılaştırmasını içermektedir. Birinci grup, bölüme meslek okulları mezuniyetinden sonra uygulanan geçiş sınavı ile kabul edilmiş öğrenciler, diğer grup ise merkezi sınav puanına göre yerleştirilmiş standart öğrencilerden oluşmaktadır. İlk grubun ayırt edici özelliği, iki yıllık mesleki eğitimden sonra lisans eğitimine geçmeleridir. Bu grup, önceki öğrenim bakımından almış oldukları önlisans eğitimi nedeniyle, diğer gruba göre farklı bir arka plana sahiptir. Bilindiği gibi, tasarım stüdyosu, tasarım sürecini ve öğrencilerin performanslarının gözlemlenebilmesi için oldukça uygun bir ortamdır. Tasarım stüdyolarındaki öğrenci faktörü ise, tasarım eğitiminin içeriğini geliştirme hedefiyle yoğun olarak tartışılmaktadır. Bu çalışma kapsamında, tasarım stüdyosu ortamında bu iki grubun başarı koşullarının bilimsel olarak değerlendirilmesi amaçlanmaktadır. Standart öğrenciler ve geçiş öğrencilerinin başarı düzeyleri, tasarım stüdyolarının performanslarına göre karşılaştırılmıştır. Sonuç olarak geçişöğrencilerinin başarı durumlarında, önceki öğrenime bağlı istatistiksel olarak anlamlı bir fark bulunamamıştır. Ancak stüdyo sürecinde gerçekleştirilen gözlem ve grup görüşmeleri yoluyla, öğrencilerin tasarım stüdyosu performanslarına ilişkin bazı nitel çıkarsamalarda bulunulmuştur.

Anahtar Kelimeler: Tasarım eğitimi, İçmimarlık eğitimi, Tasarım stüdyosu, Stüdyo pedagojisi, Öğrenci profili

Geliş Tarihi: 15.06.2020 Kabul Tarihi: 07.09.2020 Makale Türü: Araştırma Makalesi

*Eskişehir Teknik Üniversitesi, Mimarlık ve Tasarım Fakültesi, İ̧̧mimarlık Bölümü, MAK106, 26555, Eskişehir, Türkiye. ozlemkurt@eskisehir.edu.tr, ORC ID 0000-0002-9992-2472

**Eskişehir Teknik Üniversitesi, Fen Fakültesi, İstatistik Bölümü, ORC ID 0000-0002-6172-5449

***Eskişehir Teknik Üniversitesi, Mimarlık ve Tasarım Fakültesi, İçmimarlık Bölümü, ORC ID 0000-0002-4815-8179 


\section{INTRODUCTION}

As in all departments where design education is given, student profile and studio environment are significant factors in structuring the curriculums and strategies for interior design education. The studio environment constitutes the most intensive courses in a design department. The primary objective in terms of learning outcomes in interior design studios is to provide the student with the ability to produce solutions in the face of certain given design problems.

The aim of this study is to make a scientific evaluation by means of a case study for the success level of two different student profiles in design studios, which are the most basic and comprehensive learning processes in interior design education. The main reason why the study was based on that comparison was the observation of the transition students experiencing proficiency and adaptation problems due to differences between the interior design program, which is a undergraduate degree in the field of design, and the associate degree programs they came from. The research questions that led to the study consist of questioning whether there is a difference between the success levels of two student profiles accepted in different forms within the course. When the literature was examined, there is no study similar to the subject was encountered. The reason might be that the issue is related to a very particular situation about some regulations in student placement in Turkey. In the scope of the study, it was thought that it would be possible to compare the performances of the students in the course in the most accessible and objective way through their grades. To accomplish this, Student's t-Test and Two-way ANOVA was used to compare the performances of the students. In the literature, it is seen that Student's t-Test and Two-way ANOVA are frequently used to make similar evaluations in educational studies (Kang, 2018; Babapour, 2018).
In the field of education, it is observed that the main focus generally concerns the 'learner'. In this context, there have been many studies on the learner profile and the teacher profile. However, in the field of design education, studies on the learning process constitute a majority. In addition to the 'learner', it is noted that the 'learning style' is being discussed more intensively. Most of the recent studies on the design studio are based on computer-aided design or distant learning (Demirbas and Demirkan 2003: 437-438). A number of other studies deal with the design studio as an environment or with the process within the studio. (Gurel, 2010; Garip and Garip, 2012; Brandt et al., 2013; Schneiderman and Freihoefer, 2013). However, there have been few studies directly related to the learner profile in the design studio. (Demirbas and Demirkan, 2000; Cho, 2017). The learner profile has an important role in the development of design studio learning processes in which the most fundamental qualifications are acquired in interior design education. The quality of the learner's experience is also a determining factor for the correct functioning of the course process. In recent research regarding design education, it would be efficacious to observe learner-focused behavior, and to recognize the learner closely, in order to understand the learning processes correctly.

Subsequent sections contains the scope of the study, the concept of studio learning, the design studio's content in detail and the detailed information about the participants of the study. The general frame includes the research questions and the explanations of main aim of the study. The concept of studio learning has a major importance on the study in terms of the general structure. For, the success levels of student groups which is the subject of this study, were examined in a design studio environment and design process. 


\subsection{Scope of the Study}

Undergraduate programs, such as interior design, product design, fashion design and architecture accept a certain number of students each year who have completed the relevant departments at vocational schools. In countries where it is possible to transfer to design schools through examinations applied for after vocational education, standard students of the departments and students coming from vocational education institutions, form two different student profiles according to the educational backgrounds previously obtained. The main research questions of this study are as follows:

- Is there any difference between transition students and standard students' interior design studio performance caused by their different backgrounds?

-When all design studio courses that have taken until graduation are evaluated, what is the success condition of the two student profiles?

- What are the challenges faced by student groups in the design studio and do individual differences have an impact on this?

The scope of the study regarding student types is schematized on Figure 1 below.
The idea that there may be differences in the design learning processes among these student groups, allocated according to the acceptance status, and the possibility of observing these differences according to their success levels in the design studios, constitute the main research problem of this study. The assessments of course instructors on the differences in success of students who arrive with different acceptance requirements have been observed in design schools for many years. It is known that comparisons based on in-class observations have been expressed, especially in some institutions such as department of interior design, where changes in the student acceptance format have been experienced since its establishment. For instance, in the department where this study was conducted, the acceptance of students is decided by a special talent exam organized by the department committee and, since 2012, the acceptance of students with quantitative weighted scores is performed through the central examination system. The scope of this study consists of those students who have been accepted through the vertical transition examination after their education at vocational education schools and those students who have been accepted via the central examination system and have not received any previous design education.

\section{Interior Design Students}

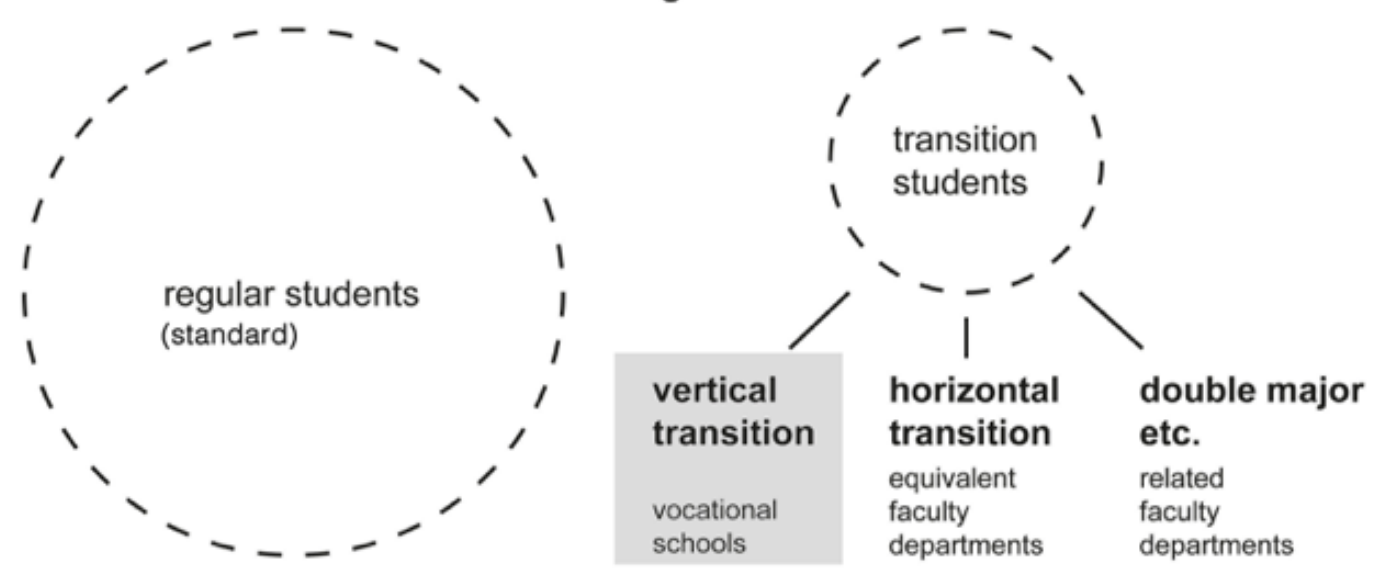

Figure 1 The classification of interior design student profiles in Turkey according to acceptance types 


\subsection{Participants}

The studio where the case study was carried out is the main course of the first semester of the second year in the department. The students have had only one design studio experience before this course. There are a total of fifteen students, but the group is characterized by the presence of two separate student profiles based on their previous level of education. One of the student profiles is a group of six students who have been accepted to the department through a national central examination called the Vertical Transfer Exam which is applied throughout the country every year. This exam is applied to the transition from two-year vocational education institutions to four-year undergraduate programs related to the field of graduation. The Evaluation, Selection and Placement Center (OSYM) carries out procedures related to the vertical transfer of associate degree holders to undergraduate programs. Last year, students and graduates of vocational schools or the Faculty of Open Education had to take the Vertical Transfer Examination from Associate to Undergraduate Degree Programs in order to be placed into undergraduate programs in related facultiesi. The vocational schools in Turkey are specified with description and related competencies formed according to the European Qualifications Framework Report. An associate (two-year) degree is given to those graduating from vocational schools and as a higher education level, QF-EHEA, Short Level EQFLLL, corresponds to Level 5. The equivalents in the European Qualifications Framework of undergraduate and graduate levels in Turkey are shown in the table below. ${ }^{1}$

\begin{tabular}{|c|c|c|c|}
\hline $\begin{array}{l}\text { HIGHER EDUCATION } \\
\text { LEVELS }\end{array}$ & \multicolumn{3}{|c|}{ GIVEN DEGREES / QUALIFICATIONS } \\
\hline $\begin{array}{l}\text { Doctorate } \\
\text { QF-EHEA: 3rd Level } \\
\text { EQF-LLL: 8th Level }\end{array}$ & Doctorate & Master in Medicine & Proficiency in Art \\
\hline $\begin{array}{l}\text { Master } \\
\text { QF-EHEA: 2nd Level } \\
\text { EQF-LLL: 7th Level }\end{array}$ & \multicolumn{2}{|c|}{ Master with thesis } & Master without thesis \\
\hline $\begin{array}{l}\text { Undergraduate } \\
\text { QF-EHEA: 1st Level } \\
\text { EQF-LLL: 6th Level }\end{array}$ & \multicolumn{2}{|c|}{$\begin{array}{l}\text { Undergraduate (Bachelor) } \\
\text { (Faculty programs) }\end{array}$} & $\begin{array}{l}\text { Undergraduate (Bachelor) } \\
\text { (Conservatory programs) }\end{array}$ \\
\hline $\begin{array}{l}\text { Associate Degree } \\
\text { QF-EHEA: Short Level } \\
\text { EQF-LLL: 5th Level }\end{array}$ & \multicolumn{2}{|c|}{$\begin{array}{c}\text { Associate degree } \\
\text { (Faculty undergraduate programs) }\end{array}$} & $\begin{array}{l}\text { Associate degree (Vocational } \\
\text { Schools) }\end{array}$ \\
\hline
\end{tabular}

Table1. Turkey Higher Education System Levels and learning outcomes each with different efficiencies in one Level. Cited from EQF (2018).

'EQF, (2018). European Qualifications Framework Report. The Directorate General for Education and Culture (DG EAC). Report. (0nline). 18-19. Accessed 20/06/19 
The learning outcomes relevant to Level 5 is described in the Table 2 that taken from Turkey Higher Education Qualifications Framework. ${ }^{2}$

\begin{tabular}{|c|c|c|c|}
\hline & Knowledge & Skills & $\begin{array}{l}\text { Responsibility and } \\
\text { autonomy }\end{array}$ \\
\hline & $\begin{array}{l}\text { In the context of EQF, } \\
\text { knowledge is described } \\
\text { as theoretical and/or } \\
\text { factual. }\end{array}$ & $\begin{array}{l}\text { In the context of EQF, } \\
\text { skills are described as } \\
\text { cognitive (involving the } \\
\text { use of logical, intuitive } \\
\text { and creative thinking) } \\
\text { and practical (involving } \\
\text { manual dexterity and the } \\
\text { use of methods, } \\
\text { materials, tools and } \\
\text { instruments). }\end{array}$ & $\begin{array}{l}\text { In the context of the } \\
\text { EQF, responsibility and } \\
\text { autonomy are described } \\
\text { as the ability of the } \\
\text { learner to apply } \\
\text { knowledge and skills } \\
\text { autonomously and with } \\
\text { responsibility. }\end{array}$ \\
\hline $\begin{array}{l}\text { Level } 5 \text { [1] } \\
\text { The learning outcomes } \\
\text { relevant to Level } 5 \text { are: }\end{array}$ & $\begin{array}{l}\text { Comprehensive, } \\
\text { specialised, factual and } \\
\text { theoretical knowledge } \\
\text { within a field of work or } \\
\text { study and an awareness of } \\
\text { the boundaries of that } \\
\text { knowledge. }\end{array}$ & $\begin{array}{l}\text { A comprehensive range of } \\
\text { cognitive and practical } \\
\text { skills required to develop } \\
\text { creative solutions to } \\
\text { abstract problems. }\end{array}$ & $\begin{array}{l}\text { Exercise management and } \\
\text { supervision in contexts of } \\
\text { work or study activities } \\
\text { where there is } \\
\text { unpredictable change; } \\
\text { review and develop } \\
\text { performance of self and } \\
\text { others. }\end{array}$ \\
\hline $\begin{array}{l}\text { Level } 6[2] \\
\text { Learning outcomes } \\
\text { relevant to Level } 6 \text { are: }\end{array}$ & $\begin{array}{l}\text { Advanced knowledge of a } \\
\text { field of work or study, } \\
\text { involving a critical } \\
\text { understanding of theories } \\
\text { and principles. }\end{array}$ & $\begin{array}{l}\text { Advanced skills, } \\
\text { demonstrating mastery and } \\
\text { innovation, required to } \\
\text { solve complex and } \\
\text { unpredictable problems in } \\
\text { a specialised field of work } \\
\text { or study. }\end{array}$ & $\begin{array}{l}\text { Manage complex technical } \\
\text { or professional activities } \\
\text { or projects, taking } \\
\text { responsibility for decision- } \\
\text { making in unpredictable } \\
\text { work or study contexts; } \\
\text { take responsibility for } \\
\text { managing professional } \\
\text { development of } \\
\text { individuals and groups. }\end{array}$ \\
\hline
\end{tabular}

Table 2. Descriptors defining levels in the European Qualifications Framework. Cited from TYYC. (2011).

The subject of the study consists of two groups of students. The Department of Interior Design accepts a significant number of students from certain associate degree programs through the vertical transfer examination each year. These students form a different student profile from the standard students in the department due to their previous vocational education programs. The other group consists of six students. The standard students of the department, which constitutes the other student profile, have been admitted to the department through the Student Selection and Placement System which is an annual central examination. This group consists of eight students and they have been placed to the department based on their quantitative score of the examination which is applied throughout the country. There is not any other criteria or exam type of the department. The transition group has been accepted to the department of interior design after two years of associate degree education. These programs, which they completed, are the Furniture-Decoration and Restoration departments. When their previous education programs were examined, it can be clearly stated that the transition group had taken similar courses in terms of content with the interior design education program, such as

${ }^{2}$ TQF (TYYC). (2011). Turkish Qualifications Framework. Accessed 10/06/19. http://tyyc.yok.gov.tr/?pid=20 
technical drawing and computer aided drawing in the vocational high schools where they successfully completed. Therefore, it is known that they are more experienced in subjects such as technical drawing and presentation techniques than the standard group. However, in general, it was effective to determine the subject of the study that the teaching staff had the prejudice that the transition group was more disadvantageous in terms of their creative aspects were weaker. Regardless of these general opinions that constitute the factors shaping the study, it was observed during the course that both groups of students had certain common characteristics and attitudes in the face of the design problem given in the studio. One of the students on the course was excluded from the study because she was a former student of the department and she was accepted through the special talent examination which is the previous student recruitment format of the department.

\subsection{Studio Learning}

The design studio is the most suitable environment for observations and research on student behavior and student success. Doubtless, project studio is the essence of professional education (Cordan et al., 2014: 191). The design studio is the main tool in teaching the main elements of design education. The first of these is that the students acquire presentation and visualization skills. Another point is that students learn the professional language. Exploring and explaining ideas through drawing is a new experience for students. Through the experiences in the studio, the design student gains the power of thinking and expression in design, while at the same time being able to dominate the common language of expression that addresses all disciplines under the roof of design (Ledewitz, 1985).

The concept of design is reinforced and internalized by the design process in the studio environment. During the design process, a given design problem is turned into a design solution, and a continuous dialogue between student and instructor enhances the design progression (Demirkan, 2016: 32). Kvan (2001: 347-348) explains that design teaching generally begins with introducing a design problem which includes project features, curriculum attributes (duration, outcomes), and objects. Design education involves lecture and studio teaching together to engage students with design knowledge, skills and practice. (Sagun, Demirkan and Goktepe, 2001:336). Project-based learning can successfully encompass user-centered tools. With an emphasis on learning rather than teaching, project-centered programs are suggested since students learn self-direction, and manage their time and resources, therefore allowing a better preparation for professional practice (Altay, 2013: 142). Also 'practice' is another key concept of design studios. Today, it is the basic pedagogical approach of the action design studio, which is widely known and used as 'learning by doing' or 'knowing in action'. Schön defines 'reflective practice' as occurring when skilled practitioners responded tacitly to situations of uncertainty, instability, or uniqueness, through a combination of intuitive 'knowing-in-action' (Webster, 2008: 65; Schon, 1987: 22), 'reflection-in-action' (Schon, 1987: $26)$ and 'reflection-on-action' (Schon, 1985: 74). Active components for realizing an effective studio communication are 'design studio as a communication medium, 'design task or problem', 'design knowledge' and 'different communication media', and the people are 'student-designers and studio instructors' (Paker-Kahvecioğlu, 2001). Project-based learning may be defined in various ways by different educational disciplines and levels. Projects are frequently used in K-12 education, so it is a concept and teaching method that is familiar to most students. (Mills and Treagust 2003: 8). In university-level design 
education, project-based learning contains the majority of the learning methods used in design programs. In the content of a design project, to share knowledge about current design approaches and research, design process development skills and tools, as well as technical issues related to presentation, are discussed. As a subject of this study, in a course that includes all these processes, the standard student profile of the department and the transferred students who had received vocational education previously are observed in terms of their success levels.

\subsection{Design Studio Content}

This study was formed based on the process of the design studio named Interior Design Project 2 in the department of interior design. The students that took this studio are the sophomore students. There are six interior design studios in the curriculum of the department. These studios are; Interior Design Project I (sophomore year), Interior Design Project II (sophomore year), Interior Design Project III (junior year), Interior Design Project IV (junior year), Interior Design Project V (senior year) and Interior Design Project VI (senior year/graduation project). Within the scope of the Bologna process, in accordance with the principles adopted as a department, the students were given detailed written information describing the project. As a methodology, the aim was to activate the design thinking processes by asking students to make three-dimensional models from the second week after the subject was transferred to the student and the research stage. As the subject of the project, the students were asked to design a fair stand for a sailing training firm. The fair stand, planned to be designed, will be located in an indoor space of $600 \mathrm{~cm} \mathrm{x} 300 \mathrm{~cm}$ in the fair area as contiguous modules. In terms of course content and learning outcomes, designing a fair stand includes corporate identity, brand identity, and design problems that require many skills and much knowledge, such as building effective human-space relationships in a limited space, and also have the potential to use creative design methods. For these reasons, the fair stand was chosen as the project subject and it was predicted that it would contribute to the development of the interior design skills of the students intensively. The weekly schedule of studio is given on Table 3. It includes the subject, theme and tasks of each week.

\begin{tabular}{cccc}
\hline Week & Subject & Theme & Task \\
\hline $\mathbf{1}$ & fair (promotion) stand & conceptual approach & research \\
$\mathbf{2}$ & fair (promotion) stand & conceptual approach & research + sketching \\
$\mathbf{3}$ & fair (promotion) stand & conceptual approach & research + modeling \\
$\mathbf{4}$ & fair (promotion) stand & conceptual approach & research + modeling \\
$\mathbf{5}$ & fair (promotion) stand & project development & sketching + modeling \\
$\mathbf{6}$ & fair (promotion) stand & project development & sketching + modeling \\
$\mathbf{7}$ & fair (promotion) stand & project development & technical drawing + \\
& & modeling \\
$\mathbf{8}$ & fair (promotion) stand & submission + final & final technical drawings + \\
& & jury & final model \\
\hline
\end{tabular}


The student group was informed about the training firm that they would be designing the stands for, and they were asked to conduct research to include the brand and corporate identity of the company. The duration of the project was determined for the first half of the spring period and the project process was continued and finalized with a 1/20 scale model, technical drawings and presentation order. The criteria of jury assesment on Table 4 .

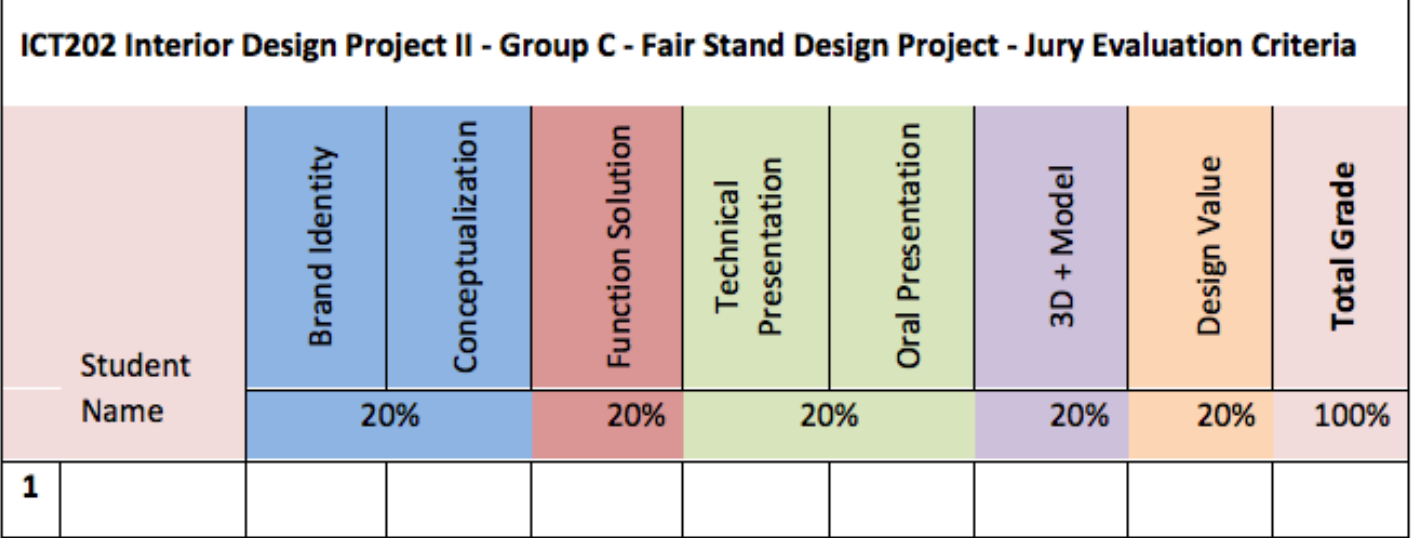

Table 4. The chart for evaluation criteria of jury

The evaluation phase was carried out by a jury consisting of two professional interior designers, as well as two academic interior designers. In order to evaluate the exhibition stand design, which is the subject of this project, the evaluation criteria was created at the scale of commercial space and the relevant percentages are given in the table above. This evaluation scale was formed by an interview of the jury. The jury evaluation criteria included the following elements; 'brand identity', 'conceptualization, 'function solution', 'technical and verbal presentation', 'threedimensional expressions and model' and 'design value. The grades used in the assessment of the students' success levels were determined according to these evaluation criteria. The project subject and assessment methodology were considered as suitable subjects in terms of the development of the second year students and the learning outcomes of the design studio course. According to weekly observations during the course, it was noted that both the transition and the standard students had a number of difficulties in developing concepts and managing the design process. This fact was confirmed by an open- ended question directed at the students: 'What were the difficulties that you faced when the early stage of project?'

Some of the answers of students to the question are given below:

Student 1: 'To transfer the concept to a certain design proposal while creating and visualizing the process.'

Student 2: 'To reflect the things designed in my mind.'

Student 3: 'To create the concept and to develop it.'

Student 4: 'To able to decide what the design concept will be.'

Student 5: 'To transfer the concept to a design.'

Student 6: 'Selection of concept.'

Student 7: 'Data analysis.'

Student 8: 'Bringing function, form and aesthetics together and creating a design product. To be able to put the thoughts in my head on paper or into a three-dimensional model.' 

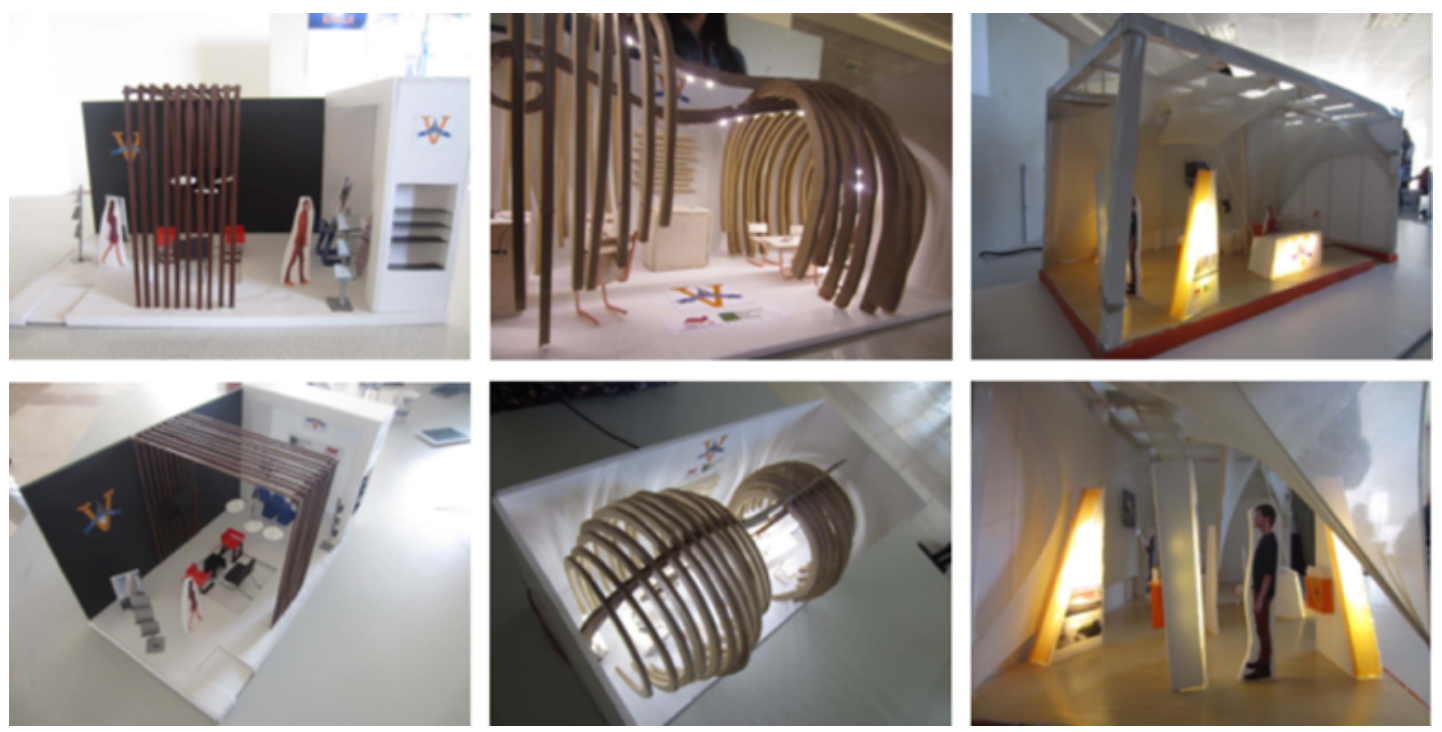

Figure 2 Sample final models (1/20 scale) from selected study teams (standard students)

In the answers given by the students, the majority came up with responses that focused on the difficulty in improving concepts and reflecting it to the design. Design and concept words were found more frequently in content analysis based on the verbal expressions of the transition students in the interviews with these students. This provides a preliminary idea that the transition group have more difficulties in establishing a concept-design relationship. The preliminary knowledge formed as a result of this observation was effective in the emergence of the research questions of this study.

On the day of the jury assessment, certain evaluations were made based on qualitative observations regarding the students. According to the 'function solution' criterion, it can be seen that the graphic elements used in the place are
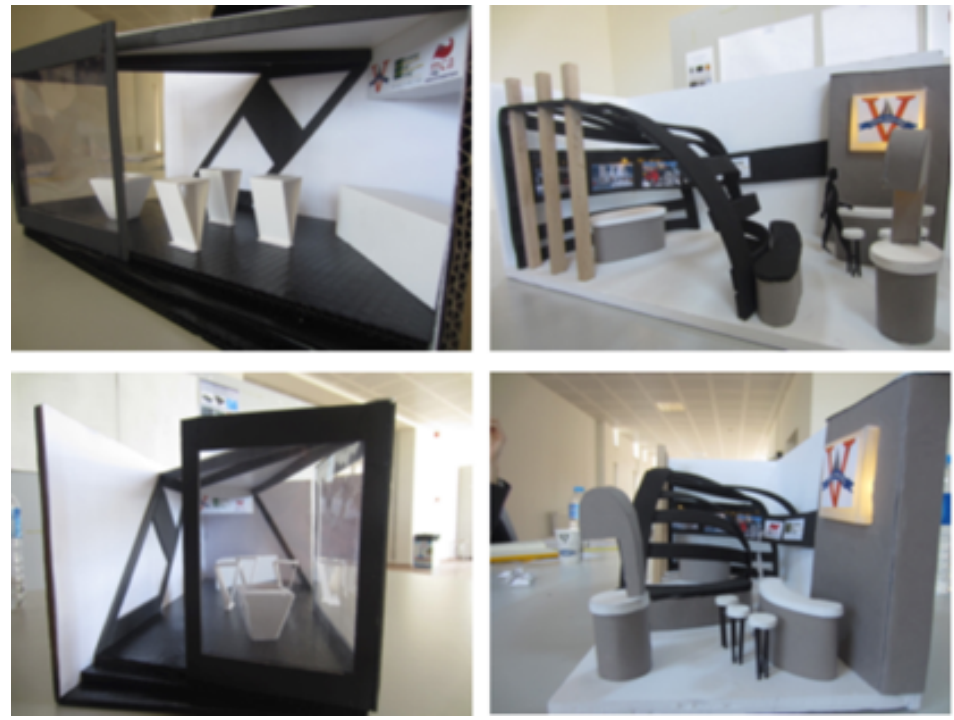

Figure 3 Sample final models (1/20 scale) from selected study teams (transition students)




installed without consideration of the human factor and, in this respect, ergonomic conditions are not taken into consideration by either student group. These evaluations were made on the models of both groups in Figure 2. and 3.

Functional problems, such as inefficient use of space, were observed in both student profiles. According to observations made during the jury process, both groups exhibited similarities according to the ' $3 \mathrm{~d}$ and model' criterion in terms of model-making techniques and use of materials. According to the 'brand identity' criterion, it was observed that all of the students showed inadequacies regarding their visual and cultural backgrounds related to fair stand design. The research that students were asked to conduct regarding brand identity was found to be lacking. According to the 'conceptualization' criterion, it was observed that students had difficulty in creative thinking and transferring creative ideas to the design stage. However, according to observations made during the lesson and focus group interviews, statements about difficulty were more common in the transition group. The 'design value' criterion is a direct aesthetic evaluation of the exhibition stand design, which has a significant impact on the final jury grades. Although the two groups were close to each other with regard to the technical presentation criterion, the transition group was found to be generally more successful. Finally, in terms of the 'verbal presentation' criterion, the proportion of students who were inadequate, and those who were more proficient, in explaining their work was found to be roughly equivalent in both groups.

\section{METHODOLOGY}

The purpose of the study is to compare the success level of the students' groups in interior design education. To realize this comparison, the success levels among the groups were compared by means of grades. In order to compare the two groups based on quantitative data, the Student's t-Test and Two-way ANOVA were used. Student's t-Test is used for testing equality of two group means. It is an approach that ignores the variability of the observation values in the groups. At this point, the use of the Student's $\mathrm{t}$-Test is effective in achieving more accurate results, taking into account in-group variability. In particular, Student's t-Test is known to be suitable for small groups as in this study. Winter's (2013), study further shows that a paired t-test is feasible with extremely small Ns if the withinpair correlation is high. When comparing the two groups, it is necessary to examine the measures of variability of these groups as well as the measures of centrality, such as mean and median. Two-way ANOVA for testing equality of several group means under block designs. Firstly, the equality of the grades of standard and transition students in Project II is tested. Then, the effects of 'student profile' and students' all project courses briefly 'projects' on the students' scores are investigated. The results are given in Sec. 4.3.

The scores of the students' groups in the project courses at the 4-point scale are considered in the statistical analysis as in Table 5.

The statistical methods are introduced in the following subsections.

\begin{tabular}{c|cccccccc|cccccc}
\hline Project & \multicolumn{7}{|c|}{ Standard students } & \multicolumn{5}{c}{ Transition students } \\
\hline I & 2.3 & 4 & 2 & 1.7 & 2.7 & 2.3 & 4 & 2.7 & 3.3 & 3 & 3.3 & 2.7 & 4 & 3 \\
II & 2 & 3.3 & 2.3 & 3 & 2 & 2.3 & 3 & 3.3 & 2.7 & 2.3 & 2 & 2.7 & 2.3 & 2.7 \\
III & 1.7 & 2.7 & 2.7 & 2.3 & 1.3 & 1.3 & 3 & 3.3 & 3 & 2.7 & 2.7 & 3.3 & 2.3 & 2.3 \\
IV & 1.7 & 2 & 2.7 & 3 & 1.7 & 3.3 & 4 & 2.7 & 0 & 2.7 & 3 & 2.3 & 3.7 & 1.7 \\
V & 0 & 3.3 & 3.3 & 3.3 & 1 & 2.7 & 4 & 2.3 & 1.7 & 4 & 3.3 & 2.3 & 3.3 & 3 \\
& \multicolumn{8}{|c}{ Table 5 The scores of the students for project courses }
\end{tabular}




\begin{tabular}{|c|c|c|c|c|}
\hline & Treatment 1 & Treatment 2 & $\ldots$ & Treatment $\boldsymbol{t}$ \\
\hline Block 1 & $y_{1 b 1}, y_{1 b 2}, \ldots, y_{1 b k}$ & $y_{211}, y_{212}, \ldots, y_{21 k}$ & $\ldots$ & $y_{t 11}, y_{t 12}, \ldots, y_{t 1 k}$ \\
\hline Block 2 & $y_{1 b 1}, y_{1 b 2}, \ldots, y_{1 b k}$ & $y_{221}, y_{222}, \ldots, y_{22 k}$ & $\ldots$ & $y_{t 21}, y_{t 22}, \ldots, y_{t 2 k}$ \\
\hline$\cdots$ & $\cdots$ & $\cdots$ & $\cdots$ & $\cdots$ \\
\hline Block $\boldsymbol{b}$ & $y_{1 b 1}, y_{1 b 2}, \ldots, y_{1 b k}$ & $y_{2 b 1}, y_{2 b 2}, \ldots, y_{2 b k}$ & $\ldots$ & $y_{t b 1}, y_{t b 2}, \ldots, y_{t b k}$ \\
\hline
\end{tabular}

Table 6 Data structure of the two-way ANOVA model

\subsection{Student t-Test}

The most used method for comparing the means of two independent groups is called the twosample Student's t-Test (Wilcox, 2009). Let $\mu \_1$ and $\mu \_2$ represent the two population means, and the goal is to test the null hypothesis in (1).

$$
\text { H_0: } \mu \_1=\mu \_2
$$

The null hypothesis means that the means of the two populations are equal. If the p-value of the Student's t-Test is lower than the nominal level, the null hypothesis is rejected and the difference between two means, is statistically significant.

\subsection{Two-Way ANOVA}

Variability arising from a nuisance factor may affect results in any analysis. A nuisance factor may be defined as a factor which has an effect on the dependent variable, but we are not interested in this effect. As a result, we need to clean the effect of the nuisance factor on the response. Consider, there are $t$ treatments and b blocks and the ith treatment is applied to all blocks, $\mathrm{i}=1,2, \ldots, \mathrm{t}$ and the data structure is shown as in Table 6 .

The null hypothesis in (2) means that the $\mathrm{k}$ populations are equal which is tested in two-way ANOVA.

$$
\text { H_0: } \mu \_1=\mu \_2=\ldots=\mu \_k
$$

If the p-value of the two-way ANOVA is lower than the nominal level, the null hypothesis is rejected and the difference between means of $\mathrm{k}$ populations, is statistically significant (Montgomery, 2005).

\section{FINDINGS}

The equality of the scores of standard and transition students in project II is tested by using Student's t-Test.

Consider mean of the transition students' grades is $\mu \_t$ and the mean of the standard students' grades is $\mu \_r$. The null hypothesis is given in (3).

$$
\text { H_0: } \mu \_t=\mu \_r
$$

The test statistic is calculated as $-0,00503$, degrees of freedom is 13 and the p-value is 0,9961 . It is concluded that there is no evidence to reject the null hypothesis because of the p-value is not lower than the nominal level 0,05. The mean of the student groups' scores are not different at the 95 percent cofidence level.

Effects of 'student profile' and 'projects' on the students' scores are investigated by two-way Analysis of Variance (ANOVA) Model. In this

\begin{tabular}{lc}
\hline Groups & \multicolumn{1}{c}{ Grades } \\
\hline Standard & $50,75,60,66,56,78,76,66$ \\
Transition & $56,57,75,56,78,62$ \\
\hline
\end{tabular}

Table 7 The grades of the students for Project II 


\begin{tabular}{llllll}
\hline & df & sum of squares & $\begin{array}{l}\text { mean of } \\
\text { squares }\end{array}$ & F-value & p-value \\
\hline 'student groups' & 1 & 0.0100 & 0.0043 & 0.0050 & 0.9420 \\
'projects' & 4 & 2.8500 & 0.7120 & & \\
Residuals & 62 & 50.760 & 0.7931 & & \\
\hline
\end{tabular}

Table 8 Two-way ANOVA Output of the effects of 'student groups' and 'projects' on the students' scores.

analysis, the nuisance factor is 'projects' and the response is the students' scores. Consider mean of the students' scores is $\mu \_t$ and the mean of the standard students' grades is $\mu \_r$. The null hypothesis is given in (4) and the output of the two-way ANOVA model is given in Table 8.

$$
\text { H_0: } \mu \_t=\mu \_r
$$

The particular rows that we are interested in are the 'student profile' and 'projects'. These rows inform us whether the factors (the 'student profile' and 'projects' rows) have any statistically significant effect on the response; students' scores. It is first necessary to examine the p-values of the factors, as this will determine how results can be interpreted. The $\mathrm{p}$-value of less than 0.05 indicates that the factor has a significant effect on the response. It can be seen from the table above that there was no statistically significant difference in student scores between the 'transition' and the 'standard' students ( $\mathrm{p}=$ 0.942).

\section{CONCLUSION AND DISCUSSION}

\section{Conclusion of the Comparison}

In this study, the objective is to make a scientific evaluation on the students who have been accepted to the department with different qualifications on a design studio. In order to better understand design student's experience and attitude, which are effective factors in field of design pedagogy today. The aim is to investigate different student types' studio experiences by examiming their level of success. By contrast with the general view that existed before the study, it has been found that there is no significant difference between the two groups of differing potential, and that the success levels of the groups are extremely close to each other. As an other prediction contrary to that prediction, it was seen that the idea that the transition group could be more successful in the studio due to their previous training and learning in the close field of design was inaccurate. However, when the grades of each student of the groups are examined, it can be seen that the difference between the lowest and highest grades is greater in the standard group. The grades of the transition group are closer to each other. Based on this finding, it can be said that the transition group consists of students with similar success levels. There is a more noticeable difference between the most successful and the least successful students in the standard group. To conclude, it has been found that there is no significant difference in success level between the two groups, contrary to the serious differences considered to exist by instructors, and the assumption at the beginning of the study was changed in terms of its accuracy.

\section{Qualitative Insights about Design Studio}

According to qualitative observations, it is assumed that the students of the standard group are more successful in developing creative thinking and concepts, because the transition group students have discourses in which they have difficulty in thinking creatively and concept development in their oral expression. However, according to the results of the statistical method based on the final grades, it is concluded that the transition student group could have achieved an equal success level. This could have been achieved 
by them being evaluated with a higher grade by the jury, according to the criteria related to technical drawing, presentation and visualization skills and modeling. In addition, interviews with the jury members support this conclusion.

Other results related to the project content within the framework of design education are as follows. Firstly, it was observed that students from both profiles had insufficient knowledge regarding fair stand design. Secondly, difficulties in recommending the use of effective space in a small-scale project, such as a stand, especially in terms of spatial function, were observed in the process they experienced. This situation was observed in models and technical drawings at the end of the course. Both groups were found to have been inadequate in terms of their visual and cultural knowledge of fair stand design and their knowledge of the human factor in interior space. It is noted that the current material and detailed information regarding the exhibition stand application is quite limited. In order to overcome such a deficiency, certain suggestions have been developed in the context of interior design education. In the curriculum, courses including materials and production techniques relating to previous periods can be intensified. From the first year in the department of interior design, formal technical trips to various spaces can be organized to increase student awareness and technical knowledge.

\section{Future Studies}

Today, the student profile is at the center of developments and transformations in the educational paradigms. The suitability of the curriculum for the learner profile determines the quality of the learning outcomes at the primary level. In addition to the differences brought by different generations with the effect of the changing age, the new learner profile includes individuals with many different backgrounds. The education of a field that is closely related to the innovative values of the 21 st century, especially design, should take into account the learner profile when creating the curriculum. With this point of view, in future studies, different student profiles can be evaluated according to the form of admission to the design schools. Student profiles in design departments are among topics that have been discussed by instructors over many years. In particular, the fact that students coming from sub-disciplines, or who are subject to different acceptance criteria, have received the same design education in recent times causes them to be compared. One of the most intriguing examples of this issue might be the investigation of the differences in performance and success levels among students who are accepted through the special talent examination and the group ranked according to the quantitative exam score. The subject of this study is only one of the profiles formed according to admission type. 


\section{REFERENCES}

- Altay, B. (2014). User-centered design through learner-centered instruction. Teaching in Higher Education, 19 (2), 138-155.

- Babapour, M., Ahangari, S. and Ahour, T. (2018). The effect of shadow reading and collaborative strategic reading on EFL learners' reading comprehension across two proficiency levels. Innovation in Language Learning and Teaching, 13 (4), 318 330.

- Brandt, C. B., Cennamo, K., Douglas, S., Vernon, M., McGrath, M. and Reimer, Y. (2013). A theoretical framework for the studio as a learning environment. International Journal of Technology and Design Education, 23 (2), 329-348.

- Cho, J. Y. (2017). An investigation of design studio performance in relation to creativity, spatial ability, and visual cognitive style. Thinking Skills and Creativity, 23 (2017), 67-78.

- Cordan, O., Gorgul, E., Numan, B. and Cincik, B. (2014). Curriculum development in interior architecture education: ITU case. ITU A|Z Journal, 11 (1), 185-197.

- Demirbas, O. O. and Demirkan, H. (2000). Privacy dimensions: A case study in the interior architecture design studio. Journal of Environmental Psychology, 20 (1), 53-64.

- Demirbas, O. O. and Demirkan, H. (2003). Focus on architectural design process through learning styles. Design Studies, 24 (5) $437-456$.

- Demirkan, H. (2016). An inquiry into the learning-style and knowledge-building preferences of interior architecture students. Design Studies, 44 (3), 28-51.

- Garip, B. and Garip, E. (2012). Addressing Environmental Design in Interior Architecture Education: Reflections on the Interior Design Studio. Procedia - Social and Behavioral Sciences, 51, 972-979.

- Gurel, M. O. (2010). Explorations in teaching sustainable design: A studio experience in interior design/architecture. International Journal of Art and Design Education, 29 (2), 184-199.

- Kang, S. (2018). Motivation and Preference for Acoustic or Tablet-Based Musical Instruments: Comparing Guitars and Gayageums. Journal of Research in Music Education, 66 (3), 278-294.

- $\quad K v a n$, T. (2001). The pedagogy of virtual design studios. Automation in Construction, 10 (3), 345-353.

- $\quad$ Ledewitz, S. (1985). Models of Design in Studio Teaching. Journal of Architectural Education, 38 (2), 2-8.

- McDonagh, D. and Thomas, J. (2010). Disability + relevant design: Empathic design strategies supporting more effective new product design outcomes. Design Journal, 13 (2), 180-198.

- Mills, J. E. and Treagust, D. F. (2003). Engineering Education: Is problem-based or project-based learning the answer. Australasian Journal of Engineering Education, 3 (2), 2-16.

- Paker-Kahvecioğlu N. (2001). PhD thesis: Interaction of Knowledge and Creativity in Architectural Design Education, Istanbul: Istanbul Technical University.

- Sagun, A., Demirkan, H. and Goktepe, M. (2001). A framework for the design studio in web-based education. International Journal of Art and Design Education, 20 (3), 332-342.

- Schneiderman, D. and Freihoefer, K. (2013). The Prefabricated Interior Design Studio: An Exploration into the History and Sustainability of Interior Prefabrication. International Journal of Art and Design Education, 32 (2), 226-242.

- Schön, D. (1985). The design studio: An exploration of its traditions and potential. London: Royal Institute of British Architects Publications.

- Schön, D. A. (1987). Educating the reflective practitioner: Toward a new design for teaching and learning in the professions. San Francisco: Jossey-Bass.

- Webster, H. (2008). Architectural Education after Schon: Cracks, Blurs, Boundaries and Beyond. Journal for Education in the Built Environment, 3 (2), 65.

- Winter, J. C. F. (2013). Using the student's t-test with extremely small sample sizes. Practical Assessment, Research and Evaluation

'Anadolu University Admission by Vertical Transfer from Associate to Undergraduate Degree Programs Code. Accessed 20/04/19. https://www. anadolu.edu.tr/en/open education/admission/admission-by-vertical-transfer-from-associate-to-undergraduate degree-programs. 


\section{References Of Figures}

- $\quad$ Figure 1. The classification of interior design student profiles in Turkey according to acceptance types. Kurt Çavuş, Ö. (2019). Personal graphic scheme.

- $\quad$ Figure 2. Sample final models (1/20 scale) from selected study teams (standard students)

- $\quad$ Figure 3. Sample final models (1/20 scale) from selected study teams (transition students) 